Original Article

\title{
MORPHOLOGICAL DISCRIMINATION OF GREEK HONEY BEE POPULATIONS BASED ON GEOMETRIC MORPHOMETRICS
}

\section{ANALYSIS OF WING SHAPE}

\author{
Leonidas Charistos ${ }^{1}$ \\ Fani Hatjina ${ }^{1 *}$ \\ Maria Bouga² \\ Mica Mladenovic ${ }^{3}$ \\ Anastasios D. Maistros ${ }^{4}$ \\ 'Hellenic Institute of Apiculture, Hellenic Agricultural Org. 'DEMETER', \\ Nea Moudania, 63 200, Greece \\ ¿Lab of Agricultural Zoology and Entomology, Agricultural University of Athens, \\ 75 lera Odos Str., Athens, 11855, Greece \\ ${ }^{3}$ Faculty of Agriculture, University of Belgrade, Nemanjina 6, 11080 Zemun, \\ Belgrade, Serbia \\ 4 MELETITIKI S.E.M-H Ltd, 36 D. Soutsou Str., Athens, 11521, Greece \\ *corresponding author: fhatjina@instmelissocomias.gr \\ Received 25 June 2013; accepted 24 February 2014
}

\begin{abstract}
A bstract
Honey bees collected from 32 different localities in Greece were studied based on the geometric morphometrics approach using the coordinates of 19 landmarks located at wing vein intersections. Procrustes analysis, principal component analysis, and Canonical variate analysis (CVA) detected population variability among the studied samples. According to the Principal component analysis (PCA) of pooled data from each locality, the most differentiated populations were the populations from the Aegean island localities Astypalaia, Chios, and Kythira. However, the populations with the most distant according to the canonical variate analysis performed on all measurements were the populations from Heraklion and Chania (both from Crete island). These results can be used as a starting point for the use of geometric morphometrics in the discrimination of honey bee populations in Greece and the establishment of conservation areas for local honey bee populations.
\end{abstract}

Keywords: Apis mellifera, geometric morphometrics, Greece, morphological discrimination.

\section{INTRODUCTION}

Traditionally, intraspecific taxonomy of the honey bee Apis mellifera $\mathrm{L}$. has been based on morphology. Twenty-seven subspecies of $A$. mellifera are currently recognized on the basis of morphometric characteristics (Ruttner, 1988, 1992; Sheppard et al., 1997; Engel, 1999; Sheppard and Meixner, 2003). These subspecies are also described as 'geographic races' because their distributions correspond to distinct geographic areas. Five evolutionary lineages have been characterized based on morphometric, molecular, ecological, ethological, and physiological traits (De la Rùa et al., 2005). Four of these lineages occur in the Mediterranean Basin: African lineage $(A)$, West and North European lineage $(M)$, South-east Europe lineage (C), and Near and Middle East lineage (0) (Garnery et al., 1993; Arias and Sheppard, 1996; Franck et al., 2000, 2001; Miguel et al., 2007; Cánovas et al., 2008).

Traditional morphometrics, so-called classical morphometry, was the only method to describe the diversity of honey bees for a long time (Ruttner, 1988), but biochemical methods have been developed (i.e., allozymes, isoenzymes) (Nunamaker and Wilson, 1982; Badino et al., 1988; Bouga et al., 2005b; Ivanova et al., 2012) for such studies. Molecular markers, such as nuclear DNA (Hall, 1990; 
Tarès et al., 1993), mitochondrial DNA (mtDNA) (Moritz et al., 1986; Smith et al., 1989; Smith, 1991; Hunt and Page, 1992; Garnery et al., 1993; Oldroyd et al., 1995; Arias and Sheppard, 1996; Pedersen, 1996; De la Rúa et al., 2000), and microsatellites (Estoup et al., 1993; Garnery et al., 1998), are also used to study genetic variability in honey bees.

Several attempts have been made to simplify morphological determination, such as reducing the number of characters (Dedej and Nazzi, 1994; Cermak and Kaspar, 2000), using a single wing cell (Francoy et al., 2006), or using computer software designed specifically for morphometric measurements (Daly et al., 1982; Batra, 1988; Tofilski, 2004). Dupraw (1964, 1965a, b) was the first to use a set of quantitative characteristics for wing venation and correctly classified many subspecies. In 1978, Daly and Balling successfully applied this method to differentiate Africanized and European honey bees in South America. Later, Daly et al. (1982) began to use digital measurements to investigate the morphometrics of honey bees, significantly reducing the time necessary for measuring, storing, and analyzing the data. Since that time, considerable research focusing on a wide range of problems by using multivariate methods has been published (Rinderer et al., 1990, 1993; Crewe et al., 1994; Quezada-
Euán et al., 2003). Steinhage et al. (1997) developed a semi-automated method for wing measurement that reduced analysis time and improved precision in identifying bee species; this method was later improved to an automated system (Steinhage et al., $2001,2007)$ with a precision of $99.8 \%$ for classifying bee species.

A new method, called geometric morphometrics, was developed based on the coordinates of landmarks located at vein intersections of the wings (Bookstein, 1991; Smith et al., 1997). The fundamental benefits of geometric morphometrics over traditional approaches include the way in which the amount of difference between shapes can be measured (using Procrustes distance), elucidation of the properties of the multidimensional shape space defined by this distance coefficient, the development of specialized statistical methods for studying shape, and the development of new techniques for graphical representation of the results (Bookstein, 1991; Rohlf, 2000; Mendes et al., 2007). The high accuracy in classification indicates that forewings carry sufficient information with which to distinguish the bee groups that are examined. In addition to molecular analysis of mtDNA origin, the methodologies are very informative.

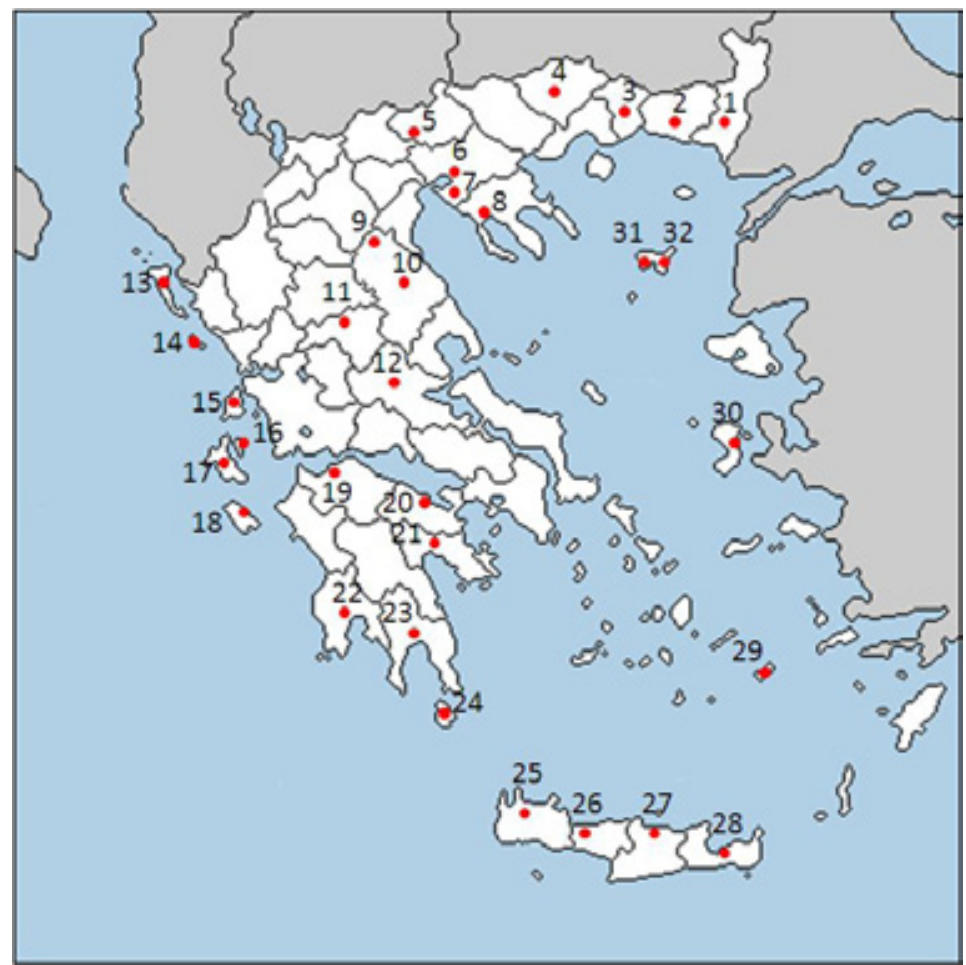

Fig. 1. Sampling localities: [1] Evros; [2] Rodopi; [3] Xanthi; [4] Drama; [5] Kilkis; [6] Thessaloniki 1; [7] Thessaloniki 2; [8] Halkidiki; [9] Elassona; [10] Larissa; [11] Karditsa; [12] Phthiotida; [13] Kerkyra; [14] Paxoi; [15] Lefkada; [16] Ithaki; [17] Kefalonia; [18] Zakynthos; [19] Achaia; [20] Korinthia; [21] Argolida; [22] Messinia; [23] Lakonia; [24] Kythira; [25] Chania; [26] Rethymno; [27] Heraklion; [28] Lasithi; [29] Astypalaia; [30] Chios; [31] Limnos 1; and [32] Limnos 2. 
The aim of this investigation was to determine if geometric morphometrics based on forewing venation is a useful tool for the discrimination of Greek honey bee populations and the establishment of conservation areas for honey bee populations that still retain some pure characteristics.

\section{MATERIAL AND METHODS}

\section{Sampling}

Honey bees were collected from 32 localities (5 non-migratory colonies/ locality, 5 bees/colony = 25 worker bees /locality). The sampling localities were North Greece (Evros, Rodopi, Xanthi, Drama, Thessaloniki 1 and 2, Halkidiki, Kilkis), Central Greece (Elassona, Larissa, Karditsa, Phthiotida) and South Greece (Argolida, Achaia, Korinthia, Lakonia, Messinia), the Aegean islands (Limnos 1 and 2, Chios,
Astypalaia, Kythira), the lonian islands (Kerkyra, Kefalonia, Lefkada, Zakynthos, Ithaki, Paxoi), and Crete island (Heraklion, Lasithi, Rethymno, Chania) (Fig. 1) corresponding to $A$. m. macedonica (North Greece), A. m. cecropia (Central and South Greece), Aegean race (near $A$. m. adami, Aegean islands), $A$. m. carnica (lonian islands), and $A$. m. adami (Crete island) in Ruttner's (1988) morphometrics analysis. The samples consisted of adult workers that were transferred alive to the laboratory and stored in 95\% ethanol until processed.

\section{Data acquisition and treatment}

The right forewings of honey bees were cut very close to their base and then transferred to $70 \%, 50 \%$, and $20 \%$ ethanol solution for gradual hydration, and finally to distilled water in order to flatten them. Images of the wings were obtained using a video camera mounted on a microscope with

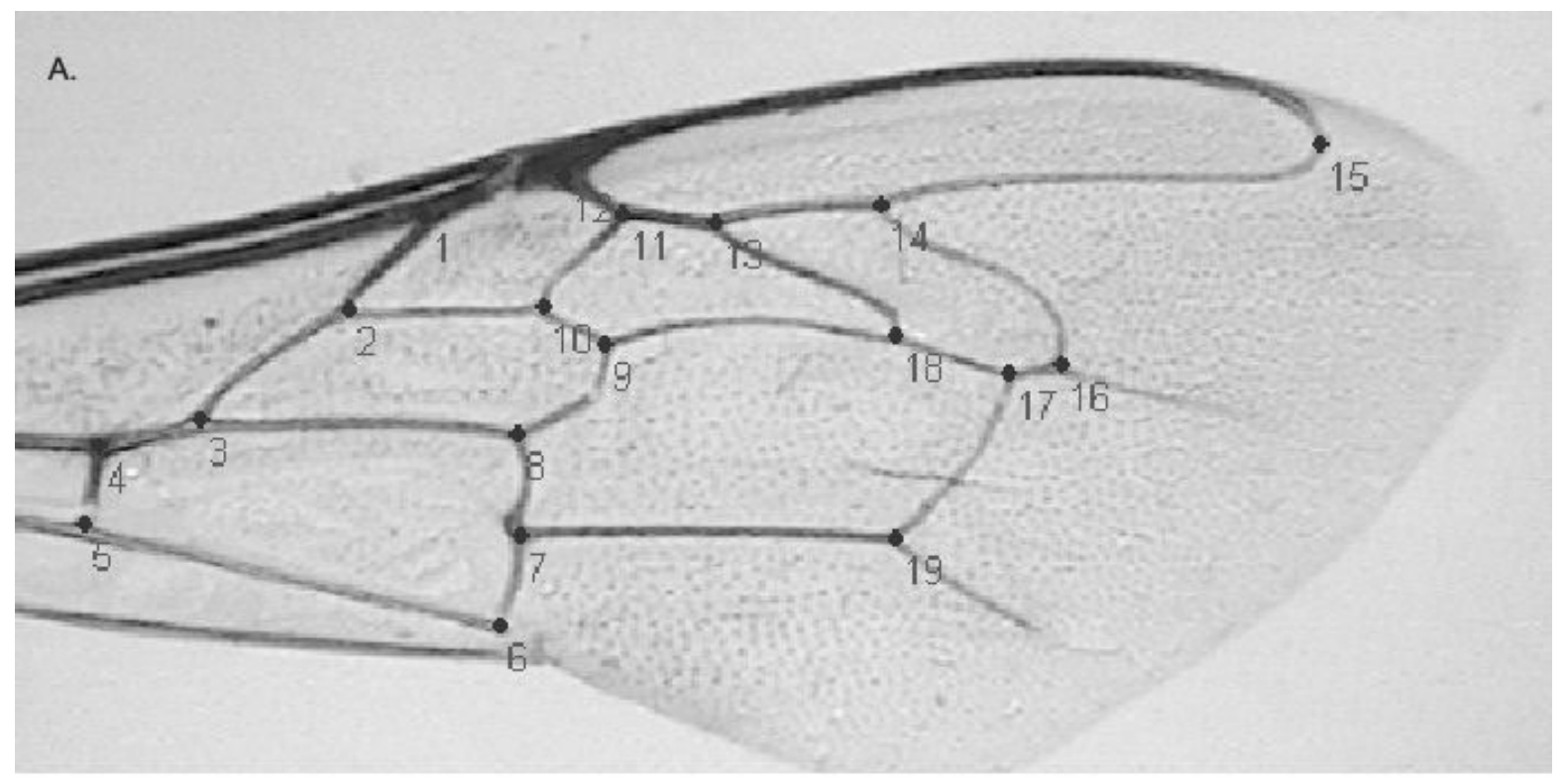

B.

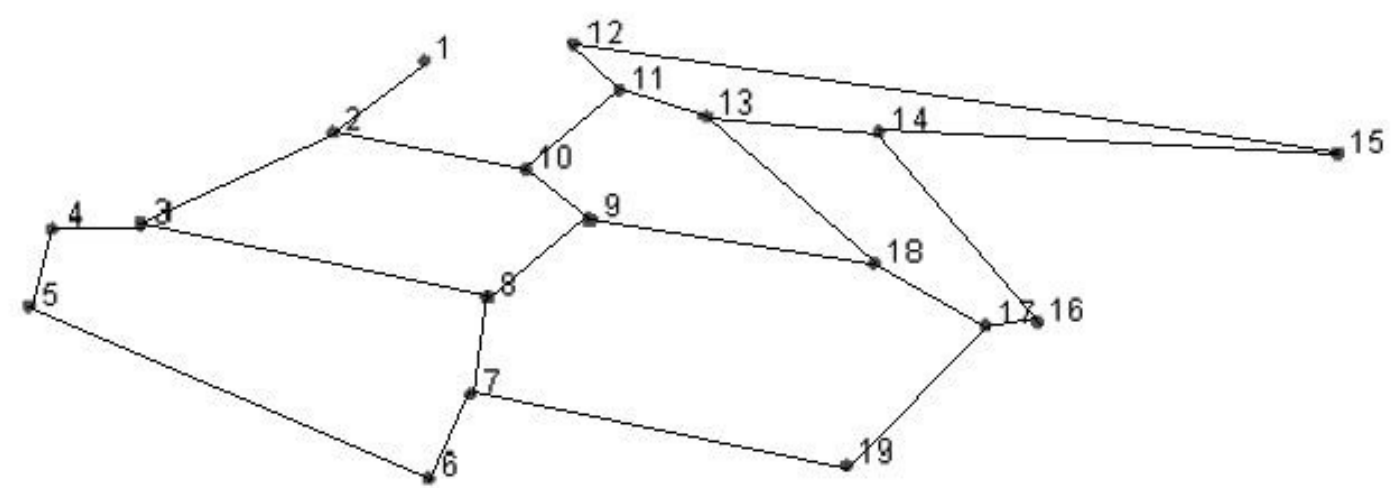

Fig. 2. The shape of the honey bee forewing. A: The coordinates of 19 landmarks located at vein intersections of the honeybee forewing. B: The average shape of the populations studied. 


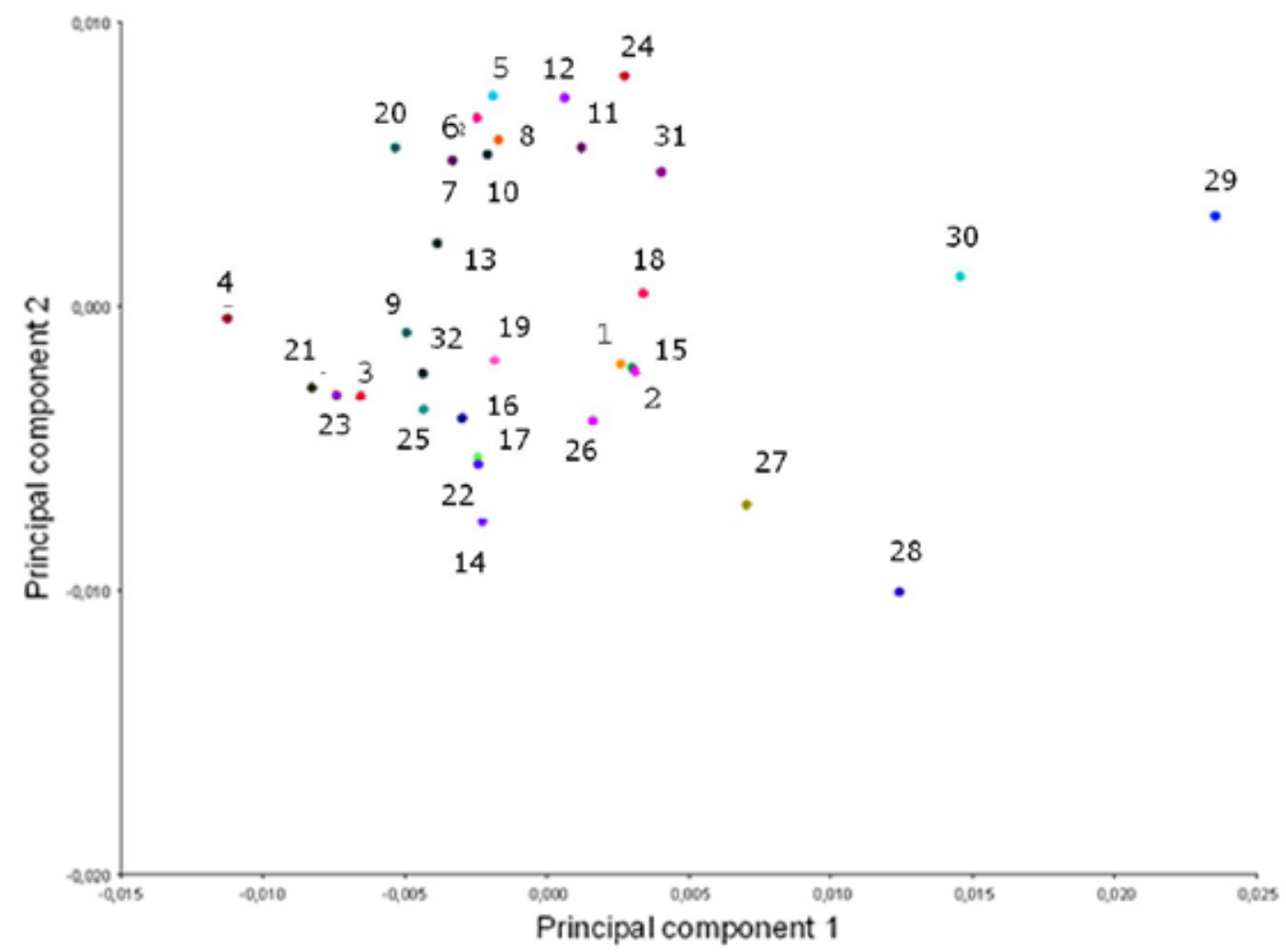

Fig. 3. Principal component analysis based on pooled data from each locality. The sampling localities are given in Fig.1. Aegean island Astypalaia [29] and Chios [30] were the most distant from the other populations, followed by Lasithi [28] and Heraklion [27] on the island of Crete. The total variance was 0.00013461 .

a $1 \mathrm{x}$ objective. The coordinates of 19 landmarks located at vein intersections (Fig. $2 \mathrm{~A}$ ) were recorded and the two-dimensional $x$, y Cartesian coordinates digitized using the tpsDig program (Rohlf, 2001). The procedure was performed twice for each wing and the average calculated in order to reduce measurement error (Miguel et al., 2010). The results for each locality were pooled.

The landmark coordinates obtained from tpsDig were used in the MORPHOJ package (Klingenberg, 2011). Alignment was performed using Procrustes fit (Procrustes superimposition) (Dryden and Mardia, 1998). Procrustes analysis (GPA), currently one of the standard methods for analyzing landmark data (Viscosi and Cardini, 2011), was performed. Procrustes distance, a measure of the absolute magnitude of the shape deviation, was calculated (Klingenberg and Monteiro, 2005). Principal component analysis (PCA) was performed based on the spectral decomposition of a covariance matrix created based on the pooled results of each locality. Principal component analysis was also performed with all measurements from each locality. Further- more, the thin-plate spline method was used to illustrate the transformations of the wing shapes compared to the average shape of the wing. Dendrograms showing the relationships among honey bee populations based on the wing shape were constructed after Fourier transformation of the pooled results of each locality according to the UPGMA method (Sneath and Sokal, 1973) using the NTSYS package (Rohlf, 1990). Canonical variate analyses (CVA) was fianlly performed with all measurements from each locality.

\section{RESULTS}

The average shape obtained by the Procrustes fit of the studied populations is shown in Fig. 2B. Procrustes distance indicated that the most distant average shape (0.0064) was found in Astypalaia (Aegean island). PCA of pooled data confirmed the differentiation of the Astypalaia population and also differentiated the populations of Chios, Lasithi, and Heraklion (Fig. 3). The principal component shape changes indicated that the populations from 


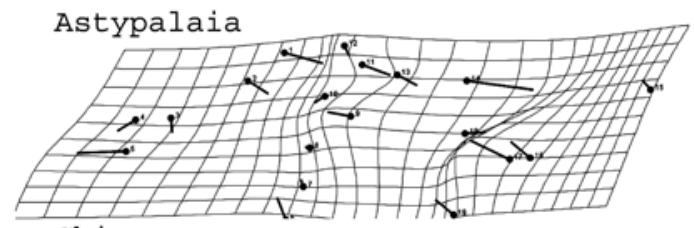

Chios
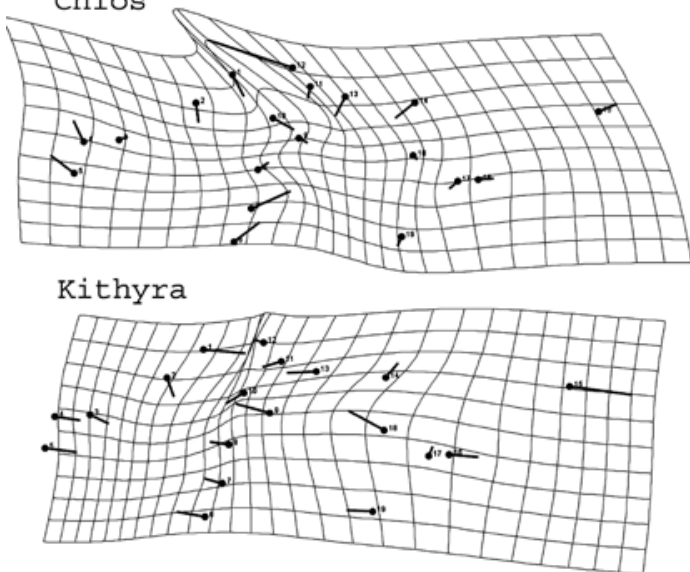

Fig. 4. The average wing shape of honey bees from Astypalaia, Chios, and Kythira and their deviations from the average shape of all populations studied. The numbers show the order of the landmarks according to Fig. 2 . The length and direction of the line indicates the movement of the respective landmark from the average shape.

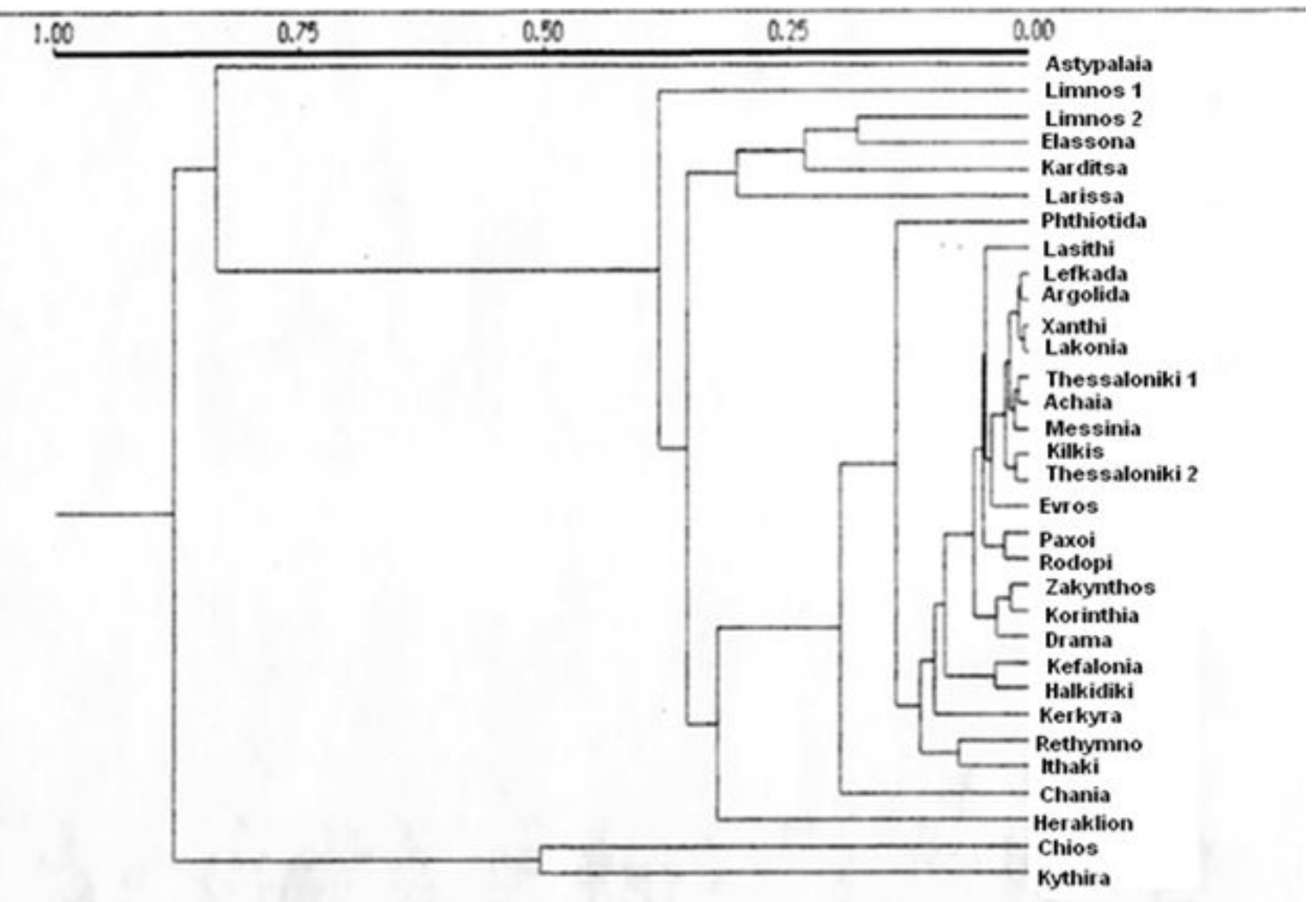

Fig. 5. UPGMA dendrogram based on the pooled results of each locality showing the phylogenetic relationships among the studied honey bee populations. The honey bee populations from Chios, Kythira and Astypalaia islands were discriminated from the rest populations. 


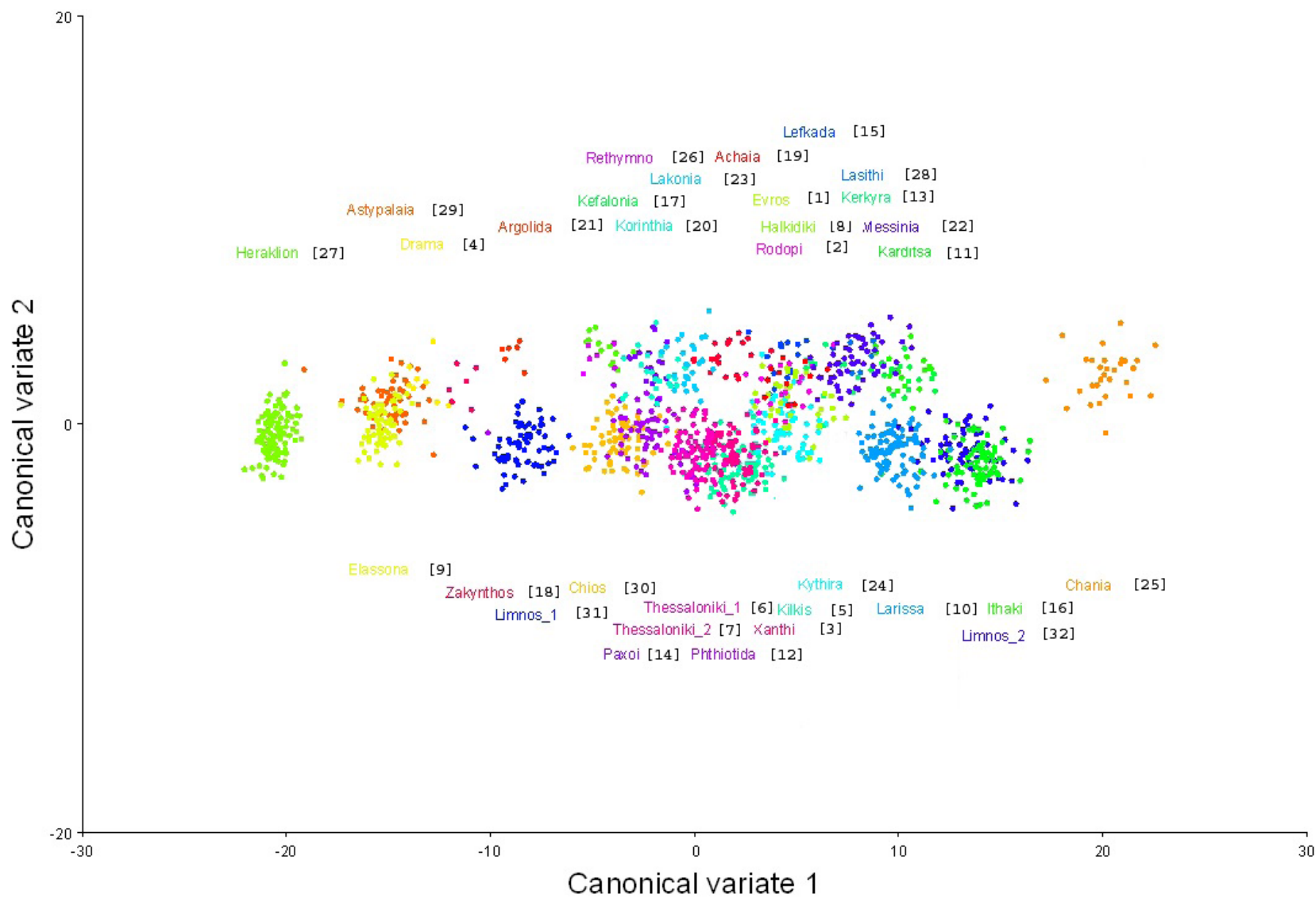

Fig. 6. Canonical variate analysis based on the measurement of all samples from each locality. Some honey bee populations were well differentiated, such as those from Chania and Heraklion (Crete island).

Astypalaia, Chios, and Kythira, all of them Aegean islands, were well separated from the rest of the studied populations. Transformation grids in Fig. 4 show the shape changes as a deformation of the rectangular grid. The total variance based on PCA was 0.00013461.

According to the topology of the UPGMA dendrogram (Fig. 5), there were two main clades initially; Chios and Kythira populations formed the first clade, whereas the other populations studied clustered together in the second clade. However, the Astypalaia population is in a distinct cluster in the second clade and all remaining populations form the second cluster. These results confirm the PCA findings. Looking further in this second cluster of the second clade, one population from Limnos was also differentiated, as well as the populations from Heraklion and Chania (Crete island). Finally, the Larissa population was the only one differentiated from among the populations of Central Greece (Fig. 5).

CVA (Fig. 6) and PCA based on all measurements gave the same results and showed a clearer differ- entiation among several of the studied populations. The most distant populations in the CVA were the populations from Heraklion and Chania (Crete island).

\section{DISCUSSION}

Identification of the species of various groups of bees based on wing features is possible, even in areas like the Mediterranean basin and Europe where many distinct subspecies exist (Kauhausen-Keller et al., 1997). Our study presents the first comprehensive study of honey bee populations in Greece using the geometric morphometrics approach. High morphological variability was found between several honey bee populations in Greece, but a mixture of populations was also found in some localities due to importation and migratory beekeeping. The most distant populations based on principal components shape changes were the populations from Astypalaia, Chios, and Kythira (all belonging to Aegean islands). Similar results were obtained in previous work based on molecular analyses, including mtDNA and 


\section{J. APCL. SCL. VOL. 58 NO. 12014}

isoenzymic analysis (Bouga et al., 2005a, b). Thus, honey bees in some Aegean islands retain distinct characteristics, probably due to reduced beekeeping movements and commercialization. Also, honey bee populations from Limnos were divided in two groups, and this result is similar to the results obtained from mtDNA analysis (Harizanis et al., 2006). Ruttner (1988) had classified the bees of the Aegean islands as an Aegean race (near $A$. m. adami).

A preliminary study on geometric morphometrics analysis of honey bee populations conducted by Hatjina et al. (2002) on a limited number of samples per locality also showed that, although a macedonica-like group was predominant in the central part of Greece, some populations originating from the Aegean islands were characteristically different, including the Astypalaia and Limnos islands. The differentiation of Astypalaia is even more interesting considering that different samples collected 10 years later showed the same results. The great number of samples and advanced methodology in this present study support the reliability of the findings.

Furthermore, the UPGMA dendrogram showed that Central Greece populations cluster closely together. Ruttner (1988) also classified the bees from Central Greece as A. m. cecropia. However, the population from Larissa was differentiated from the others, similar to previous studies concerning mtDNA analysis (Harizanis et al., 2006; Martimianakis et al., 2011). According to these studies, this population represents a unique haplotype and is characteristically distinguishable from the $A$. m. macedonica hybrids that dominate the mainland. Studying the population structure of the apiaries neighboring the one sampled would be interesting, as well as a comparison of the morphometrics results for today's bees with Ruttner's database.

As in similar studies concerning other countries (Özkan Koca and Kandemir, 2013), the CVA and PCA based on all measurements seemed to be able to detect differences between the honey bee populations from Greece. Based on these analyses, differences were detected among several Greek honey bee populations, and the most distant populations were from Heraklion and Chania (Crete island).

The use of geometric morphometrics in general confirmed what was already known from mtDNA studies; Greek honey bee populations are not classified clearly using only the discrete subspecies referred to in Ruttner's (1988) morphometrics analysis. Great hybridization exists due to beekeeping practices (commercial breeding and migratory beekeeping). However, some important variability still exists. In an attempt to preserve honey bee biodiversity through the establishment of conservations areas, these discrete populations can be used for the reproduction of local populations.

\section{CONCLUSIONS}

This study demonstrated that geometric morphometrics analysis of wing shapes can be used to discriminate several honey bee populations from Greece with both Canonical variate analysis and Principal component analysis. The presence of distinct groups was highlighted by honey bee populations from some Aegean islands, such as Astypalaia, Chios, and Kythira, and some localities of Crete island (i.e., Chania and Heraklion). The results are useful for the discrimination and preservation of local populations.

\section{ACKNOWLEDGMENTS}

We wish to thank numerous beekeepers for kindly providing the bee samples. We would especially like to thank Dr. Michel Baylac from Muséum National d'Histoire Naturelle-Paris for his help, assistance, and advice at the very beginning. Finally, we thank the anonymous referees for their constructive comments on the manuscript.

\section{REFERENCES}

Arias M. C., Sheppard W. S. (1996) Molecular Phylogenetics of Honey Bee Subspecies (Apis mellifera L.) Inferred from Mitochondrial DNA Sequence. Molecular Phylogenetics and Evolution 5: 557-566.

Badino G., Celebrano G., Manino A., Ifantidis M. D. (1988) Allozyme variability in Greek honeybees (Apis mellifera L.). Apidologie 19: 377-386. DOl: 10.1051/apido:19880405

Batra S. W. T. (1988) Automatic image analysis for the rapid identification of Africanized honey bees. In: Needham G.R. (Ed.) Africanized Honey Bees and Bee Mites. Chichester. Ellis Horwood: 260-263.

Bookstein F. L. (1991) Morphometric Tools for Landmark Data. Geometry and Biology. Cambridge University Press. New York. 435 pp.

Bouga M., Harizanis P. C., Kilias G., Alahiotis S. (2005a) Genetic divergence and phylogenetic relationships of Honey Bee Apis mellifera (Hymenoptera: Apidae) populations from Greece and Cyprus using PCR - RFLP analysis of 


\section{_ C CHARISTISS ET HL. _ Morphological discrimination of Greek honey bees}

three mtDNA Segments. Apidologie 36: 335-344. DOl: 10.1051/apido:2005021

Bouga M., Kilias G., Harizanis P. C., Papasotiropoulos V., Alahiotis S. (2005b) Allozyme variability and phylogenetic relationships in honey bee (Hymenoptera: Apidae: A. mellifera) populations from Greece and Cyprus. Biochemical Genetics 43: 471-484. DOl: 10.1007/s10528005-8163-2

Cánovas F., De la Rúa P., Serrano J., Galián J. (2008) Geographical patterns of mitochondrial DNA variation in Apis mellifera iberiensis (Hymenoptera: Apidae). Journal of Zoological Systematics and Evolutionary Research 46 : 24-30. DOl: 10.1 11 1/j.1439-0469.2007.00435.x

Cermak K., Kaspar F. (2000) A method of classifying honey bee races by their body characters. Pszczelnicze Zeszyty Naukowe (XLIV) 2: 81-86.

Crewe R. M., Hepburn H. R., Moritz R. F. (1994) Morphometric analysis of two southern African races of honeybee. Apidologie 25: 61-70.

Daly H. V., Balling S. S. (1978) Identification of Africanized honeybees in the Western Hemisphere by discriminant analysis. Journal of Kansas Entomological Society 51: 857-869.

Daly H. V., Hoelmer K., Norman P., Allen T. (1982) Computer-assisted measurement and identification of honey bees (Hymenoptera: Apidae). Annals of Entomological Society of America 75: 591-594.

Dedej S., Nazzi F. (1994) Two distances of forewing venation as estimates of wing size. Journal of Apicultural Research 33: 59-61.

De la Rúa P., Fuchs S., Serrano J. (2005) Biogeography of European honeybees. In: Lodesani M., Costa C. (Eds.) Beekeeping and Conserving Biodiversity of Honeybees. Sustainable Bee Breeding. Theoretical and practical guide. Northern Bee Books. Hebden Bridge: 15-52.

De la Rúa P., Simon U. E., Tide A. C., Moritz R. F. A., Fuchs S. (2000) MtDNA variation in Apis cerana populations from the Philippines. Heredity 84: 124-130. DOl:10.1046/ j.1365-2540.2000.00646.x

Dryden I. L., Mardia K. V. (1998) Statistical shape analysis. Wiley. Chichester. 347 pp.
Dupraw E. J. (1964) Non-Linnean taxonomy. Nature 202: 849-852. DOl:10.1038/202849a0

Dupraw E. J. (1965a) The recognition and handling of honeybee specimens in non-Linnean taxonomy. Journal of Apicultural Reasearch 19: 96-104.

Dupraw E. J. (1965b) Non-Linnean taxonomy and the systematics of honeybees. Systematic Zoology 14:1-24. DOl: 10.2307/2411899

Engel M. S. (1999) The taxonomy of recent and fossil honey bees (Hymenoptera: Apidae: Apis). Journal of Hymenopteran Research 8: 165-196.

Estoup A. L., Solignac M., Harry M., Cornuet J. M. (1993) Characterization of (GT)n and (CT)n microsatellites in two insect species: Apis mellifera and Bombus terrestris. Nucleic Acids Research 21: 1427-1431. DOl: 10.1093/ nar/21.6.1427

Franck P., Garnery L., Loiseau A. (2001) Genetic diversity of the honeybee in Africa: microsatellite and mitochondrial data. Heredity 86: 420-430. DOl: 10.1046/j.13652540.2001.00842.x

Franck P., Garnery L., Celebrano G., Solignac M., Cornuet I. M. (2000) Molecular confirmation of a Middle East lineage in Apis mellifera. Apidologie 31: 167-180.

Francoy T. M., Prado P. R. R., Gonçalves L. S., da Fontoura Costa L., De Jong D. (2006) Morphometric differences in a single wing cell can discriminate Apis mellifera racial types. Apidologie 37: 91-97. DOl: 10.1037/0003066X.59.1.29

Garnery L., Solignac M., Celebrano G., Cornuet J. M. (1993) A simple test using restricted PCR-amplified mitochondrial-DNA to study the genetic-structure of Apis mellifera L. Experientia 49: 1016-1021.

Garnery, L., Franck P., Baudry E., Vautrin D., Cornuet J. M., Solignac M. (1998) Genetic diversity of the west European honey bee (Apis mellifera and A. m. iberica). I. Mitochondrial DNA. Genetics Selection Evolution 30: 31-47. DOl: 10.1 186/1297-9686-30-S1-S31

Hall H. G. (1990) Parental Analysis of Introgressive Hybridization Between African and European Honeybees Using Nuclear DNA RFLPs. Genetics 125: 61 1-621.

Harizanis P. C., Nielsen D. I., Bouga M. (2006) Diagnostic Molecular Markers discriminating Africanized Honey 
Bee from Greek and Cypriot Honey Bees (Apis mellifera, Hymenoptera: Apidae). Journal of Apicultural Research 45(3): 197-202. DOl:10.3896/IBRA. 1.45.4.05

Hatjina F., Baylac M., Haristos L., Garnery L., Arnold G., Tsellios D. (2002) Wing differentiation among Greek populations of honey bee (Apis mellifera): a geometric morphometrics analysis. In: Book of Abstracts of 7th European Entomological Congress. Thessaloniki - Greece. 7-13 October 2002: 279.

Hunt J. G., Page Jr. E. R. (1992) Patterns of inheritance with RAPD molecular markers reveal novel types of polymorphism in the honey bee. Theoretical and Applied Genetics 85: 15-20.

Ivanova E., Bouga M., Staykova T., Mladenovic M., Rasic S., Charistos L., Hatjina F., Petrov P. (2012) Study on genetic variability of honey bees from Balkan Peninsula based on alloenzymic data . Journal of Apicultural Research 51(4): 329-33. D0l:10.3896/IBRA. 1.51.4.06

Kauhausen-Keller, D., Ruttner, F., Keller R. (1997) Morphometric studies on the microtaxonomy of the species Apis mellifera L. Apidologie 28: 295-307. DOl: 10.1051/ apido:19970506

Klingenberg C. P. (2011) Morpho J: an integrated software package for geometric morphometrics. Molexular Ecology Resources 1 1: 353-357. DOl: 10.1111/j.17550998.2010.02924.x

Klingenberg C. P., Monteiro L. R. (2005) Distances and directions in multidimensional shape spaces: implications for morphometric applications. Systematic Biology 54: 678-688. DOl: 10.1080/10635150590947258

Martimianakis S., Klossa-Kilia E., Bouga M., Kilias G. (2011) Phylogenetic relationships among A. mellifera subspecies based on sequencing of mtDNA segments. Journal of Apicultural Research 50(1): 42-50. DOl 10.3896/ IBRA. 1.50.1.05

Mendes M. F. M., Francoy T. M., Nunes-Silva P., Menezes C., Imperatriz-Fonseca V. L. (2007) Intra-populational variability of Nannotrigona testaceicornis Lepeletier 1836 (Hymenoptera, Meliponini) using relative warp analysis. Bioscience 23: 147-152.

Miguel I., Iriondo M., Garnery L., Sheppard W. S., Estonba A. (2007) Gene flow within the M evolutionary lineage of Apis mellifera: role of the Pyrenees, isolation by distance and post-glacial recolonization routes in the western Eu- rope. Apidologie 38: 141-155.

Miguel I., Baylac M., Iriondo M., Manzano C., Garnery L., Estonba A. (2010) Both geometric morphometric and microsatellite data consistently support the differentiation of the Apis mellifera M evolutionary branch. Apidologie 42: 150-161. DOl: 10.1051/apido/2010048

Moritz R. F. A., Hawkins C. F., Crozier R. H., Mckinley A. G. (1986) A mitochondrial DNA polymorphism in honey bees (Apis mellifera L.). Experientia 42: 322-324.

Nunamaker R. A., Wilson W. T. (1982) Isozyme changes in the honeybee Apis mellifera L. during larval morphogenesis. Insect Biochemistry 12: 99-104.

Oldroyd B. P., Cornuet J. M., Rowe D., Rinderer E. T., Crozier R. H. (1995) Racial admixture of Apis mellifera in Tasmania, Australia: similarities and differences with natural hybrid zones in Europe. Heredity 74: 315-325. DOl: 10.1038/hdy.1995.46

Özkan Koca A., Kandemir I. (2013) Comparison of two morphometric methods for discriminating honey bee (Apis mellifera L.) populations in Turkey. Turkish Journal of Zoology 37: 205-210. DOI: 10.3906/zoo-1 104-10

Pedersen B. V. (1996) On the phylogenetic position of the Danish strain of the black honeybee (the Laeso bee), Apis mellifera mellifera L. (Hymenoptera: Apidae) inferred from mitochondrial DNA sequences. Entomologica Scandinavica 27: 241 -250. DOI: 10.1 163/187631296X00070

Quezada-Euán J. G., Pérez-Castro E. E., May-ltzá W. J. (2003) Hybridization between European and African-derived honeybee populations (Apis mellifera) at different altitudes in Peru. Apidologie 34: 217-225.

Rinderer T. E., Buco S. M., Rubink W. L., Daly H. V., Stelszer J. A., Rigio R. M. (1993) Morphometric identification of Africanized and European honey bees using large reference populations. Apidologie 24: 569-585. DOl: 10.1051/ apido:19930605

Rinderer T. E., Daly H. V., Sylvester H. A., Collins A. M., Buco S. M., Hellmich R. L., Danka R. G. (1990) Morphometric Differences among Africanized and European Honey-Bees and Their F1 Hybrids (Hymenoptera, Apidae). Annals of Entomological Society of America 83: 346-351.

Rohlf F. J. (1990) NTSYS-pc, Numerical Taxomomy and Multivariate Analysis System. Exeter Software, N. Y. 


\section{_ C CHARISTISS ET HL. _ Morphological discrimination of Greek honey bees}

Rohlf F. J. (2000) Statistical power comparisons among alternative morphometric methods. American Journal of Physical Anthropology 1 11:463-478.

Rohlf F. J. (2001) TPSdig: digitize landmarks from image files, scanner or video. Department of Evolutionary Biology. University of New York. Stony Brook. New York.

Ruttner F. (1988) Biogeography and Taxonomy of Honeybees. Springer - Verlag, Berlin. 292 pp. DOl: 10.1007/978-3-642-72649-1

Ruttner F. (1992) Naturgeschichte der Honigbienen. Ehrenwirth Verlag. Münich. Germany. 357 pp.

Sheppard W. S., Meixner M. D. (2003) Apis mellifera pomonella, a new honey bee subspecies from Central Asia. Apidologie 34: 367-375. DOl: 10.1051/apido:2003037

Sheppard W. S., Arias M. C., Greech A., Meixner M. D. (1997) Apis mellifera ruttneri, a new honey bee subspecies from Malta. Apidologie 28: 287-293. DOl: 10.1051/ apido:19970505

Smith D. (1991) Mitochondrial DNA and honey bee biogeography. In: Smith D.R. (Ed.) Diversity of the Genus Apis. Westview Press. Oxford and IBH Publishing Co. Oxford:131-176.

Smith D. R., Taylor O. R., Brown W. M. (1 989) Neotropical Africanized honeybees have African mitochondrial DNA. Nature 339: 213-215.

Smith D. R., Crespi B. 」., Bookstein F. L. (1997) Fluctuating asymmetry in the honey bee, Apis mellifera: effects of ploidy and hybridization. Journal of Evolutionary Biology 10: 551-574. DOl: 10.1046/j.1420$9101.1997 .10040551 . x$
Sneath P. H. A., Sokal R. R. (1973) Numerical Taxonomy: The principle and practice of numerical classification. W. H. Freeman. San Francisco. 573 pp.

Steinhage V., Kastenholz B., Schröder S., Drescher W. (1997) A hierarchical approach to classify solitary bees based on image analysis. In: Paulus E., Wahl F. M. (Eds.) Mustererkennung. 19th DAGM-Symposium Braunschweig. 15 - 17 September 1997. Informatik Aktuell: 419 426. DOl: 10.1007/978-3-642-60893-3_45

Steinhage V., Schröder S., Lampe K. H., Cremers A. B. (2007) Automated extraction and analysis of morphological features for species identification. In: MacLeod N. (Ed.) Automated Object Identification in Systematics: Theory, Approaches, and Applications. pp. 1 15-129.

Steinhage V., Arbuckle T., Schröder S., Cremers A. B., Wittmann D. (2001) ABIS: Automated Identification of Bee Species. BIOLOG Workshop, German Programme on Biodiversity and Global Change. Status Report: 194-195.

Tarès S., Cornuet J. M., Abad P. (1993) Characterization of an Unusually Conserved Alu I Highly Reiterated DNA Sequence Family From the Honeybee Apis mellifera. Genetics 134: 1195-1204.

Tofilski A (2004) DrawWing, a program for numerical description of insect wings. Journal of Insect Science 4: 17-22.

Viscosi V., Cardini A. (2011) Leaf Morphology, Taxonomy and Geometric Morphometrics: A Simplified Protocol for Beginners. PLoS ONE 6: e25630-e25630. DOl: 10.1371/ journal.pone.0025630 